\title{
Infectious haematopoietic necrosis epidemic (2001 to 2003) in farmed Atlantic salmon Salmo salar in British Columbia
}

\author{
S. M. Saksida* \\ Centre for Aquatic Health Sciences, Box 277, Campbell River, British Columbia V9W 5B1, Canada
}

\begin{abstract}
I investigated a recent infectious haematopoietic necrosis disease (IHN) epidemic in farmed Atlantic salmon Salmo salar in British Columbia (BC), Canada. All companies with infected farms $(n=36)$ participated in the study. Over 12 million Atlantic salmon on infected farms died or were culled during the epidemic with cumulative mortality on the farms averaging $58 \%$. The first reported case of IHN occurred in August 2001 and the last outbreak in June 2003. Outbreaks on the farms lasted between 20 and 22 wk. Genetic sequencing by other researchers, revealed that 2 different IHN isolates contributed to this epidemic, one linked to all cases in 4 areas, the other associated with all cases in a fifth area. Spatial and temporal patterns of the farm outbreaks were examined to determine possible methods of spread between the farms. Evidence presented herein appears to show that farming practices themselves contributed significantly to the spread between farms both within and between areas. Natural waterborne transmission may have played a role in the spread of the virus between farms located in close proximity to each other. The data collected from this epidemic are compared with reports which examined the first reported epidemic in Atlantic salmon in BC (1992 to 1996). Evidence is presented for the hypothesis that wild fish species may have been the source of introduction of the virus into the farmed Atlantic salmon population.
\end{abstract}

KEY WORDS: Infectious haematopoietic necrosis $\cdot$ IHN $\cdot$ Atlantic salmon $\cdot$ Risk factors

\section{INTRODUCTION}

Infectious haematopoietic necrosis virus (IHNV) is an endemic pathogen of salmonids in western North America associated with the development of infectious haematopoietic necrosis (IHN) (Traxler et al. 1998). Ribonuclease protection assays and nucleotide sequencing of IHNV isolates collected over a $20 \mathrm{yr}$ period found that the isolates can be grouped into 3 separate regional isotypes, i.e. NW coast (Oregon to Alaska), California, and Idaho (Hsu et al. 1986, Emmenegger et al. 2000, Troyer et al. 2000, Emmenegger \& Kurath 2002, Kurath et al. 2003). Different salmonid species appear to be sensitive to different genetic isotypes. While sockeye salmon Oncorhynchus nerka are susceptible to the NW coast IHNV isolates (U genogroup), chinook salmon $O$. tshawytscha and rain- bow trout $O$. mykiss are more susceptible to the Californian (L genogroup) and the Idaho (M genogroup) isolates respectively (Kurath et al. 2003).

The first published description of IHNV in sockeye salmon appeared over 50 yr ago (Rucker et al. 1953). Most of the mortality associated with IHNV in sockeye salmon in British Columbia, occurs in the freshwater alevin and swim-up stages. Although there is anecdotal information that vertical transmission of IHNV occurs, no laboratory study has demonstrated vertical transmission of the pathogen (Traxler et al. 1997, Bootland \& Leong 1999).

Horizontal transmission of IHNV occurs readily in both saltwater and freshwater. However, disease outbreaks in the seawater sockeye stages have not been commonly observed (Traxler et al. 1998). The northwest coast isolates are quite homogeneous, indicating 
that continual mixing of the isolates has occurred over generations. The only place where such mixing would be possible would be in the ocean, possibly in the 'Alaskan gyre', the common feeding ground for all sockeye populations north of Oregon (Williams \& Amend 1976, Traxler \& Rankin 1989, Emmenegger et al. 2000, Emmenegger \& Kurath 2002).

In 1992, an IHNV epidemic occurred in farmed Atlantic salmon Salmo salar in British Columbia (BC). Over a 4 yr period, IHNV spread to 13 separate farm sites within a $20 \mathrm{~km}$ radius of the index case (Armstrong et al. 1993, St-Hilaire 2000, St-Hilaire et al. 2002). Farm level mortality associated with the outbreak ranged from 18 to $78 \%$ (St-Hilaire et al. 2002). In the summer of 2001, IHNV was again diagnosed in farmed Atlantic salmon in $\mathrm{BC}$, with the resulting epidemic becoming more widespread than the 1992 to 1996 epidemic. G. Kurath \& G. S. Traxler (pers. comm.) examined isolates collected from several affected farms during the epidemic and identified 2 isolates: one (Sequence A) associated with the outbreaks along the east coast of Vancouver Island (west coast of the BC mainland), and the second (Sequence B) found only in outbreaks on the west coast of Vancouver Island. For further details of the sequences see 'Discussion'. The present study provides a retrospective descriptive examination of the most recent IHNV outbreak, which occurred in 2001 to 2003. Spatial and temporal patterns during the outbreak were examined to ascertain possible risk factors associated with the spread of the virus.

\section{MATERIALS AND METHODS}

A questionnaire was used to obtain outbreak information and to identify potential risk factors associated with the 2001 to 2003 IHNV epidemic in BC. The survey instrument comprised both 'yes/no' questions and short answer questions. Data collected relevant to the present report included production information (e.g. fish stocking dates, number of fish, movement history), farm information (e.g. location), and specific questions pertaining to the outbreak (i.e. date occurrence first suspected, date of laboratory confirmation, mortality levels). Questions asking for details regarding noninfected farms in close proximity to the affected farm of concern were attached as an addendum to each questionnaire, and included the name and location of the unaffected farm (relative to infected farms) as well as general production data (e.g. stocking dates, number of fish, source of fish, fish movement history).

A list of all companies with IHNV-affected farms was compiled with the assistance of the $\mathrm{BC}$ aquaculture industry and provincial government agencies. Based on general discussions with the farming companies and aquaculture veterinarians, it was determined that farms outside the affected regions operated in relative isolation and were likely to have had very little contact with the affected farms (i.e. separate delivery systems, different smolt/harvest transport routes). Therefore, only companies operating Salmo salar farms in the affected areas were asked to participate in the survey. Company veterinarians, fish health biologists and/or production managers were asked to complete the questionnaire and participate in the interview. Prior to conducting a personal interview, a copy of the questionnaire was distributed to each participating company to ensure that the appropriate data would be available during the interview. A questionnaire was completed for each affected farm. Interviews were conducted in June 2002, approximately 10 mo after the first confirmed case in the 2001 to 2003 epidemic, and again in December 2003, several months after the last confirmed outbreak of IHNV.

During the December interviews, all participating companies were asked follow-up questions (e.g. weekly and cumulative mortality numbers and or rates associated with IHNV) regarding outbreaks that were ongoing at the time of the first interview. Study participants were asked to provide population sizes as well as cumulative and weekly mortality information from 1 mo prior to the IHNV outbreak to the time when the affected group was removed from the farm by either culling or harvest.

The farming companies were also asked to supply a list of contract vessels that serviced the farms during the epidemic. Shared contractors were contacted by telephone and questioned regarding vessel movement and their disinfection protocols during the time of the epidemic. Processing plants identified to have processed fish from the affected farms were contacted by telephone and questioned about biosecurity and disinfection protocols.

Because the first survey was conducted while the epidemic was still ongoing, many of the farms classified as negative during the first interview subsequently became infected and were included in the second round of interviews as outbreaks. In addition, several negative farms identified as non-infected sites in proximity to positive sites during interviews were not managed by the same company that was being interviewed so that, in such cases, with the exception of the name and location of the farm, most other questions could not be answered by the interview participant. As a result, where necessary, the farming companies operating the unaffected farms were contacted by telephone and asked an abridged list of questions regarding the unaffected farm, i.e. number of fish on site, date of stocking farm, age of fish. 
Data collected from the survey was recorded onto Excel spread sheets (Microsoft 2000). The locations of infected and non-infected farms were identified on an aquaculture map provided on the internet site jointly run by the British Columbia Ministry of Agriculture, Fisheries and Food (BCMAFF) and the Department of Fisheries and Oceans Canada (DFO) (www.fishwizard. com). Farms were categorised based on their location relative to other farms in close proximity (i.e. upstream, downstream, cross-stream, other). Distances between farms were estimated using a DFO GIS mapping program available on the internet-MAPSTER Version 2.1 (www-heb.pac.dfo-mpo.gc.ca/maps/maps-data_e.htm).

Weekly mortality data provided by the farming companies were used to construct epidemic curves and to determine the duration of the epidemic on farms. Farm level cumulative mortality was determined from data provided by farms that had maintained infected/ exposed populations for the duration of the outbreak (i.e. not immediately culled or harvested). Farm level cumulative mortality was either provided directly by the farming companies or calculated using the population size and mortality data provided; all mortalities occurring during a farm outbreak were attributed to the infection. Summary statistics and Pearson correlation analysis were calculated using STATISTIX $^{\circledR}$ for Windows (Analytical Software). A Student's $t$-test was used to compare population sizes from affected and unaffected farms. The level of significance was set at $\alpha=0.05$.

\section{RESULTS}

A total of 36 Atlantic salmon farms, operated by 5 separate aquaculture companies, experienced IHNV outbreaks during the 2001 to 2003 epidemic. All affected companies agreed to participate in the study (100\% compliance). Information regarding the outbreaks was collected during 2 rounds of interviews: in June 2002 when information from the first 19 outbreaks was obtained, and in December 2003 when the remaining 17 outbreaks and follow-ups to earlier outbreaks were investigated. In the same regions, there were 19 Atlantic salmon farms that did not experience IHNV outbreaks or mortalities during the epidemic. Abridged production data were collected from 13 of these 19 farms.

The outbreaks of IHNV on Atlantic salmon farms occurred in 5 salmon farming zones in BC: 4 along the west coast of the BC mainland (Sites 1 to 4), and 1 on the west of Vancouver Island (Site 5) (Fig. 1). The first case was diagnosed in late August 2001; the final farm outbreak of IHNV was diagnosed in June 2003, 660 d (22 mo) after the index case. Salmon populations on farms that experienced outbreaks ranged from 30000 to 1024000 salmon farm ${ }^{-1}$ (mean of 555771 salmon farm $^{-1}, \mathrm{SD}=285223$ salmon farm ${ }^{-1}$ ) and was not significantly different $(p=0.9$ ) from populations sizes on unaffected farms which ranged from 37000 to 1608000 salmon farm ${ }^{-1}$ (mean $\left.=545820 ; \mathrm{SD}=358290\right)$. Water temperatures during the epidemic period ranged from 6.7 to $12^{\circ} \mathrm{C}\left(\right.$ mean $\left.=8.6^{\circ} \mathrm{C}, \mathrm{SD}=1.25\right)$.

At the time of the farm level outbreaks, salmon populations on $47 \%$ of the farms $(n=17)$ had been in seawater for less than $1 \mathrm{yr} 47 \%$ of the farm populations ( $\mathrm{n}=17$ ) had been in seawater between 1 and $2 \mathrm{yr}$, and $5 \%$ of the farms $(n=2)$ had salmon populations that had been in seawater for more than $2 \mathrm{yr}$. Of the 13 unaffected farms from which data were collected, 5 had Atlantic salmon on site before any of the outbreaks occurred in their region, 8 received fish while new outbreaks were occurring in their region, and 1 received smolts shortly after the last outbreak occurred in its region. As a result of the staggered nature of the farm outbreaks, direct age comparisons with unaffected farms were not made.

Mortality data collected from affected farms indicate that over 12 million Atlantic salmon either directly died or were culled as a result of the 2001-2003 epidemic. Cumulative mortality estimated from data provided by 21 farms which maintained the Atlantic salmon popu-

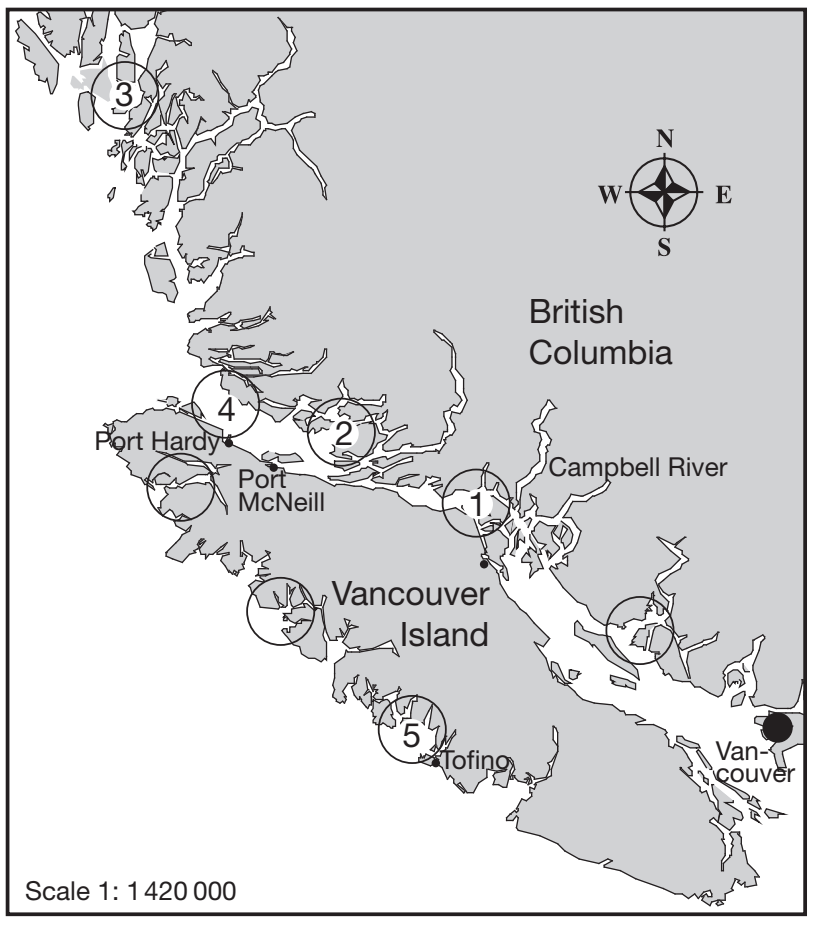

Fig. 1. Locations of Atlantic salmon Salmo salar farming regions (O) in coastal British Columbia and Vancouver Island. 1 to 5: 5 areas that experienced infections haematopietic necrosis virus (IHNV) outbreaks between 2001 and 2003 
lations on the farm for at least 14 wk of an outbreak showed mortality ranging from 20 to $94 \%$ (mean = $58.0 \%, \mathrm{SD}=19.8)$. Mortality was inversely correlated with the age of the populations at the time of the outbreak ( $\mathrm{r}=-0.71 ; \mathrm{p}<0.01)$, with higher mortality occurring in Atlantic salmon populations that had been in seawater less than $1 \mathrm{yr}$ (mean 66.7\%, SD = 13.8) than those that had been in seawater for more than $1 \mathrm{yr}$ (mean $31.9 \%$, SD = 18.0). Mortality was also examined relative to the average weight of the affected populations and again a negative correlation was found to exist $(\mathrm{r}=-0.72 ; \mathrm{p}<0.01)$, with mortality highest in populations with average weights of $<1 \mathrm{~kg}$ (mean $72 \%, \mathrm{SD}=14.4)$. Mortality of $55 \%(\mathrm{SD}=17.1)$ and $41 \%$ ( $\mathrm{SD}=16.8)$ was seen in salmon populations with average weights between 1 and $2 \mathrm{~kg}$ and $>2 \mathrm{~kg}$ respectively. Age in seawater and average weight of affected populations were positively correlated $(\mathrm{r}=0.90 ; \mathrm{p}<0.01)$.
The incubation period from apparent exposure to the virus to onset of clinical disease may have been as short as $7 \mathrm{~d}$. This is based on data collected from the first outbreak to occur (in Area 5), which showed that a group of Atlantic salmon smolts developed IHNV within 1 wk of being introduced at the farm with IHNV pre-existing in the farm population.

Detailed weekly percent mortality data were examined from 20 of 36 farms that experienced outbreaks. Typically a steep rise in the mortality rate was seen in the population subsequent to the initial suspicion of IHNV by the fish health personnel on a farm site, with mortality peaking at 6 to $8 \mathrm{wk}$ into the outbreak. This suggests that once Atlantic salmon became infected with IHNV and exhibited clinical disease, there was rapid transmission of disease throughout the entire farm. The duration of the epidemic on an Atlantic salmon farm appeared to be 20 to $22 \mathrm{wk}$.

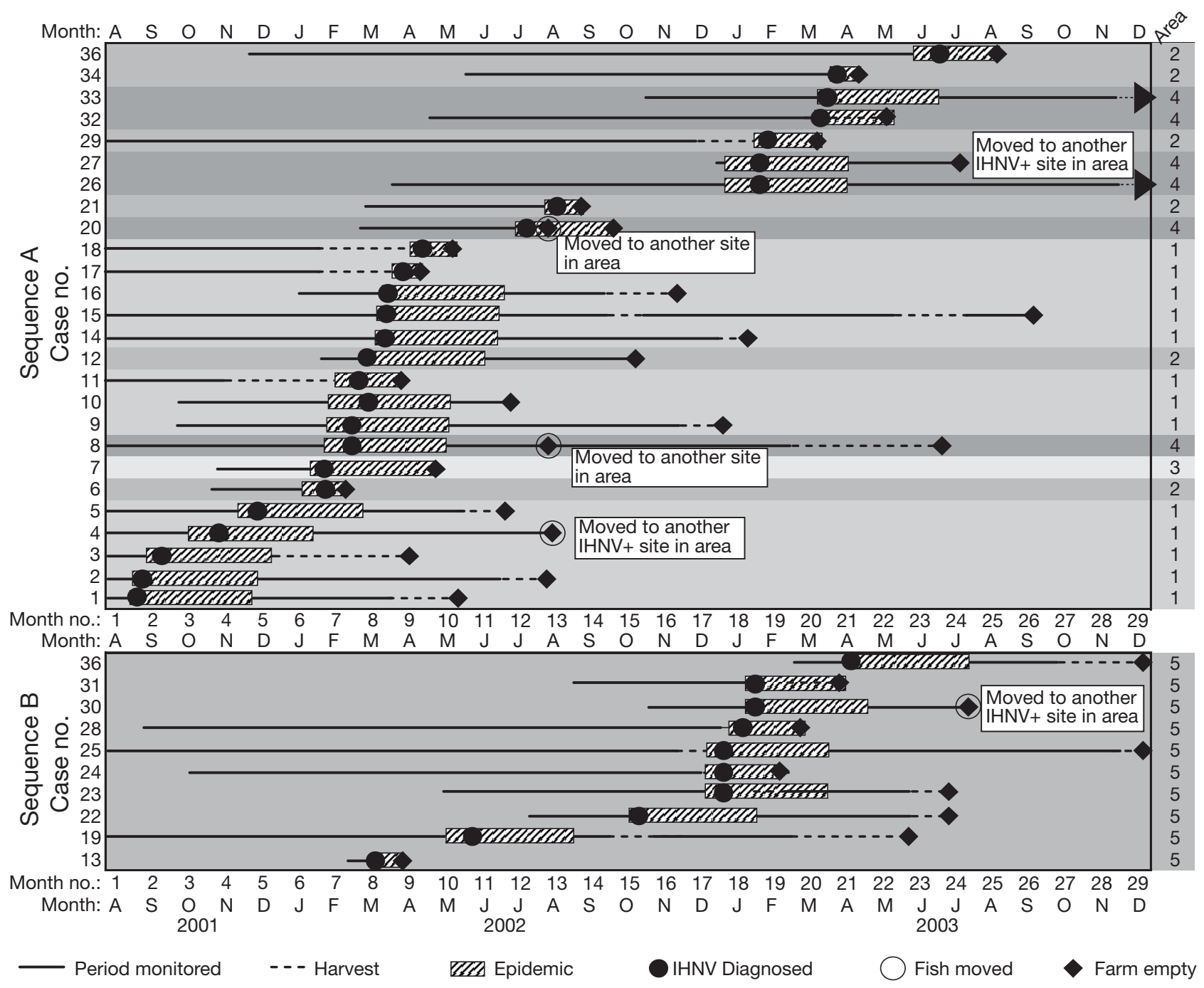

Fig. 2. Progression of IHNV epidemic in affected farms in British Columbia. Two sequences were isolated, Sequence A occurring on the east coast of Vancouver Island and west coast of the BC mainland, and Sequence B on the west coast of Vancouver Island 
Fig. 2 illustrates the temporal pattern of IHNV outbreaks on the farms for both IHNV isolates (Sequence A found only in Areas 1 to 4 and Sequence B found only in Area 5). The location of all farms in Areas 1 to 5 (including those that did not experience outbreaks) is illustrated in Figs. 3 to 7 respectively. Table 1 summarises the proximities and locations of farms that experienced new outbreaks in relation to the next closest farm on which an IHNV outbreak had occurred earlier. Location is based on an estimate of net surface water

Table 1. Farms infected with IHNV. Outbreaks in each area (chronological order), and location relative to nearest previous infected farm in respective area in $\mathrm{km}$ and in terms of net surface water flow direction (upstream, downstream, cross-stream), different channel, inlet or area. Where a farm was the first diagnosed in an area, distance to nearest farm outside the area is given. No. of days since index case/1st report: time of outbreak relative to index case in Area 1 and to first report in relevant area, respectively. Average fish wt. is average weight $(\mathrm{g})$ of the affected population. Case no.: case number in overall outbreak; shaded rows: distance and location for all unaffected farms in Areas 1, 3, and 5, and for 8 farms nearest to affected farms in Area 2

\begin{tabular}{|c|c|c|c|c|c|c|c|c|}
\hline & \multirow{2}{*}{$\begin{array}{l}\text { IHNV } \\
\text { isolate }\end{array}$} & \multirow{2}{*}{$\begin{array}{c}\text { Outbreak } \\
\text { no. }\end{array}$} & \multicolumn{2}{|c|}{ No. of days since } & \multirow{2}{*}{$\begin{array}{l}\text { Location relative to } \\
\text { nearest infected farm }\end{array}$} & \multirow{2}{*}{$\begin{array}{l}\text { Distance from } \\
\text { nearest case }(\mathrm{km})\end{array}$} & \multirow{2}{*}{$\begin{array}{l}\text { Average } \\
\text { fish wt. (g) }\end{array}$} & \multirow{2}{*}{$\begin{array}{c}\text { Case } \\
\text { no. }\end{array}$} \\
\hline & & & index case & 1 st report & & & & \\
\hline \multirow[t]{16}{*}{ Area 1} & A & 1 & 0 & 0 & & & 3000 & 1 \\
\hline & $\mathrm{A}$ & 2 & 4 & 4 & Downstream & 3 & 2490 & 2 \\
\hline & A & 3 & 12 & 12 & Downstream & 5 & 5230 & 3 \\
\hline & A & 4 & 42 & 42 & Down/Cross-stream & 6 & 660 & 4 \\
\hline & A & 5 & 80 & 80 & Cross-stream & 3 & 4580 & 5 \\
\hline & $\mathrm{A}$ & 6 & 155 & 155 & Upstream & 30 & 500 & 9 \\
\hline & A & 7 & 156 & 156 & Upstream & 1 & 96 & 10 \\
\hline & A & 8 & 161 & 161 & Downstream & 10 & 5900 & 11 \\
\hline & A & 9 & 196 & 196 & Cross-stream & 2 & 687 & 14 \\
\hline & A & 10 & 197 & 197 & Cross-stream & 4 & 1800 & 15 \\
\hline & A & 11 & 203 & 203 & Different inlet & 15 & 1800 & 16 \\
\hline & $\mathrm{A}$ & 12 & 210 & 210 & Upstream & 5 & 4630 & 17 \\
\hline & $\mathrm{A}$ & 13 & 225 & 225 & Downstream & 3 & 6800 & 18 \\
\hline & & & & & Different channel & 29 & & \\
\hline & & & & & Different channel & 31 & & \\
\hline & & & & & Different channel & 29 & & \\
\hline \multirow[t]{14}{*}{ Area 2} & A & 1 & 135 & 0 & Different area & $>100$ & 159 & 6 \\
\hline & A & 2 & 183 & 48 & Different channel & 3 & 1200 & 12 \\
\hline & A & 3 & 353 & 218 & Different channel & 30 & 290 & 21 \\
\hline & $\mathrm{A}$ & 4 & 520 & 385 & Different area & 55 & 5000 & 29 \\
\hline & A & 5 & 590 & 455 & Upstream & 5 & 6500 & 34 \\
\hline & A & 6 & 660 & 525 & Different area & 40 & 4500 & 36 \\
\hline & & & & & Upstream & 7 & & \\
\hline & & & & & Upstream & 8 & & \\
\hline & & & & & Upstream & 13 & & \\
\hline & & & & & Downstream & 13 & & \\
\hline & & & & & Downstream & 15 & & \\
\hline & & & & & Different channel & 7 & & \\
\hline & & & & & Different channel & 8 & & \\
\hline & & & & & Different channel & 10 & & \\
\hline \multirow[t]{3}{*}{ Area 3} & A & 1 & 137 & 0 & Different area & $>100$ & 176 & 7 \\
\hline & & & & & Upstream & 14 & & \\
\hline & & & & & Upstream & 17 & & \\
\hline \multirow[t]{6}{*}{ Area 4} & A & 1 & 150 & 0 & Different area & 60 & 1132 & 8 \\
\hline & A & 2 & 326 & 176 & Downstream & 8 & 418 & 20 \\
\hline & A & 3 & 502 & 352 & Downstream & 8 & 925 & 26 \\
\hline & $\mathrm{A}$ & 4 & 502 & 352 & Cross-stream & 17 & 1170 & 27 \\
\hline & A & 5 & 577 & 427 & Downstream & 20 & 4000 & 32 \\
\hline & A & 6 & 583 & 433 & Downstream & 8 & 1800 & 33 \\
\hline \multirow[t]{11}{*}{ Area 5} & B & 1 & 188 & & Different area & $>100$ & 60 & 13 \\
\hline & B & 2 & 253 & 65 & Upstream & 5 & 1900 & 19 \\
\hline & $\mathrm{B}$ & 3 & 425 & 237 & Downstream & 7 & 1590 & 22 \\
\hline & B & 4 & 486 & 298 & Different channel & 30 & 2150 & 23 \\
\hline & B & 5 & 489 & 301 & Upstream & 5 & 4100 & 24 \\
\hline & B & 6 & 491 & 303 & Upstream & 12 & 4900 & 25 \\
\hline & B & 7 & 506 & 318 & Down/Cross-stream & 3 & 3500 & 28 \\
\hline & B & 8 & 521 & 333 & Upstream & 18 & 220 & 30 \\
\hline & B & 9 & 521 & 333 & Upstream & 6 & 3500 & 31 \\
\hline & B & 10 & 597 & 409 & Downstream & 3 & 130 & 35 \\
\hline & & & & & Upstream & 10 & & \\
\hline
\end{tabular}




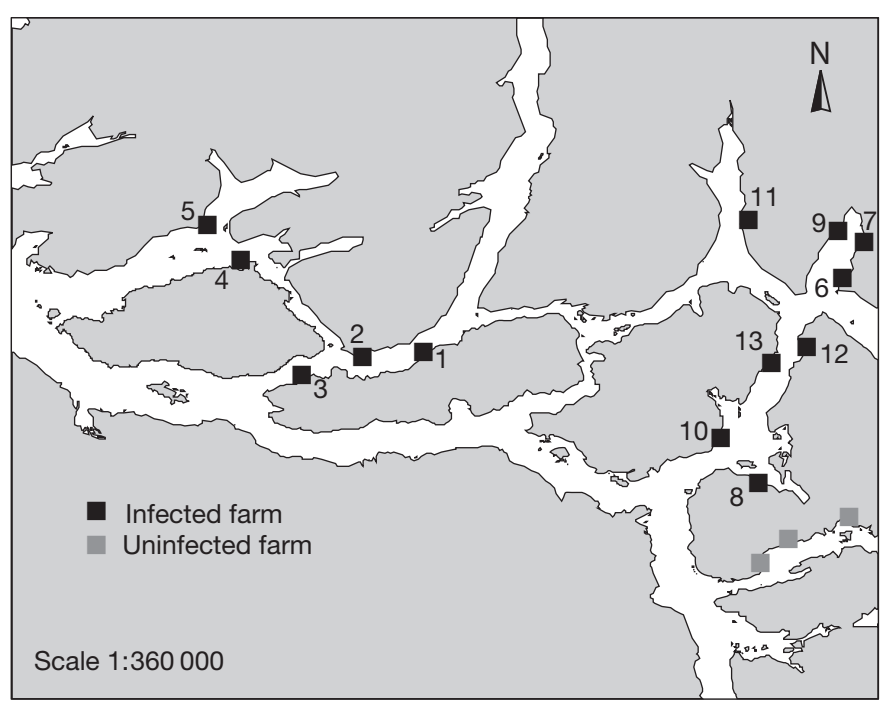

Fig. 3. Locations of farms diagnosed with IHNV (numbered) and the uninfected farms in Area 1. Numbers refer to outbreak no. in the area (Table 1). For map showing all locations see Fig. 1

flow patterns. The average size of the affected populations as well as the time (in days) between farm outbreaks are also summarised in Table 1, which additionally provides distances and locations for many of the unaffected farms relative to the farms experiencing outbreaks within the affected areas.

Area 1 (Fig. 3) is located on the east side of Vancouver Island, near Campbell River, and was the area where the first case of IHNV was recorded in August 2001. In this region, 4 aquaculture companies operated farms, and all eventually ran farms that contracted IHNV. Over a 7 mo period, 13 of $16(81 \%)$ salmon farms in Area 1 contracted IHNV. The 3 Atlantic salmon farms that remained IHNV negative in Area 1 were all located in the same channel, separate from the channels containing the farms experiencing IHNV outbreaks. As of September 2003, there were no farms with Atlantic salmon that had survived an IHNV outbreak remaining in Area 1. All affected farms in the area were cleaned and left unpopulated for a minimum of 6 mo prior to restocking.

The first outbreak of IHNV on a salmon farm outside Area 1 was located over $100 \mathrm{~km}$ north in Area 2 (Fig. 4). This area (referred to as the Broughton Archipelago) is located on the east coast of Vancouver Island near the community of Port McNeil; 2 aquaculture companies operated farms in this region. A total of 6 of the 18 farms $(33 \%)$ in this area had IHNV outbreaks. The disease was suspected on the first affected farm in the region in January 2002 and confirmed in February 2002. During the 2001 to 2003 epidemic, there continued to be several Atlantic salmon farms in Area 2 that did not contract IHNV (Fig. 4). By August 2003, all farms which had undergone outbreaks had been depopulated.
Area 3 is situated several hundred km north of Vancouver Island on the central coast of British Columbia, and all the farms are operated by 1 company. An IHNV outbreak occurred on only 1 of the 3 (33\%) farms in this area (Fig. 5). The unaffected farms were situated $20 \mathrm{~km}$ away, in a different channel from the affected farm. The affected farm was identified in January 2002. The entire population on the affected farm was culled 18 wk after the initial diagnosis.

All 6 farms operating in Area 4, located near Port Hardy, contracted IHNV (Fig. 6); 1 aquaculture company operated all of the farms in this area. The first affected farm was diagnosed in February 2002. All the

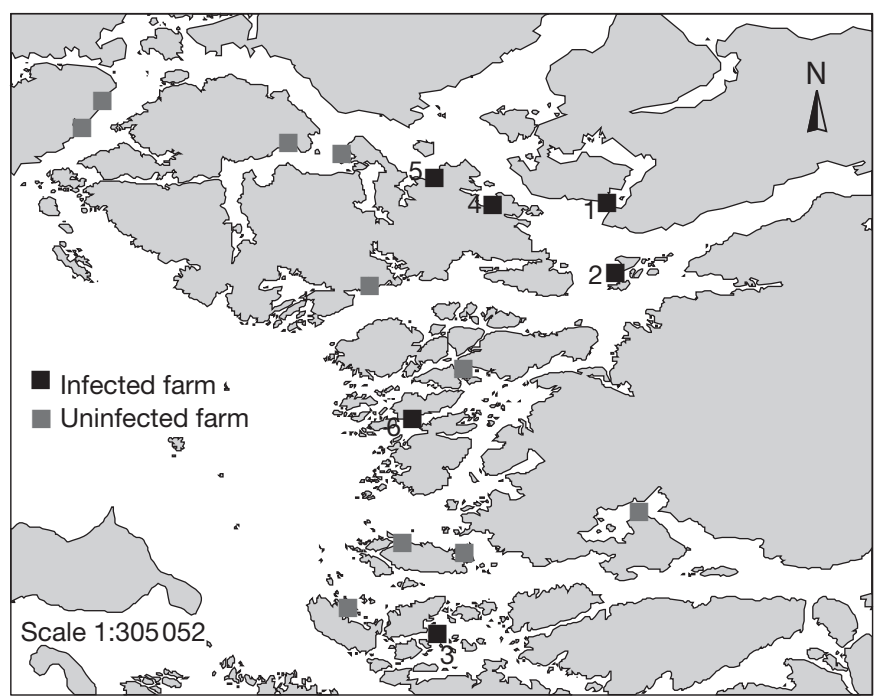

Fig. 4. Locations of farms diagnosed with IHNV (numbered) and the uninfected farms in Area 2. Numbers refer to outbreak no. in the area (Table 1). For map showing all locations see Fig. 1

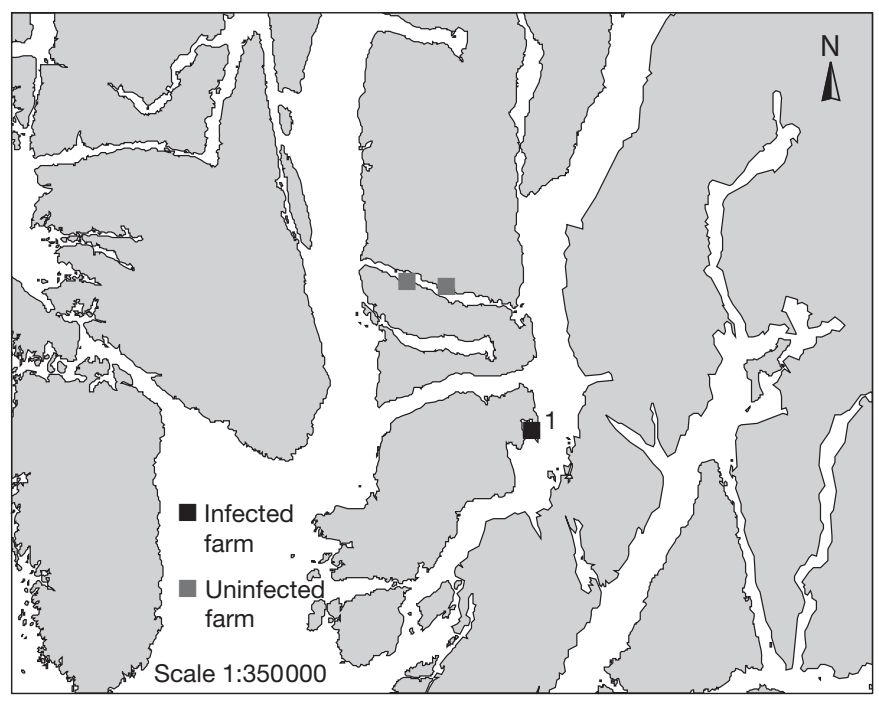

Fig. 5. Salmo salar. Locations of farm diagnosed with IHNV (numbered) and the uninfected farms in Area 3. Numbers refer to outbreak no. in the area (Table 1). For map showing all locations see Fig. 1 


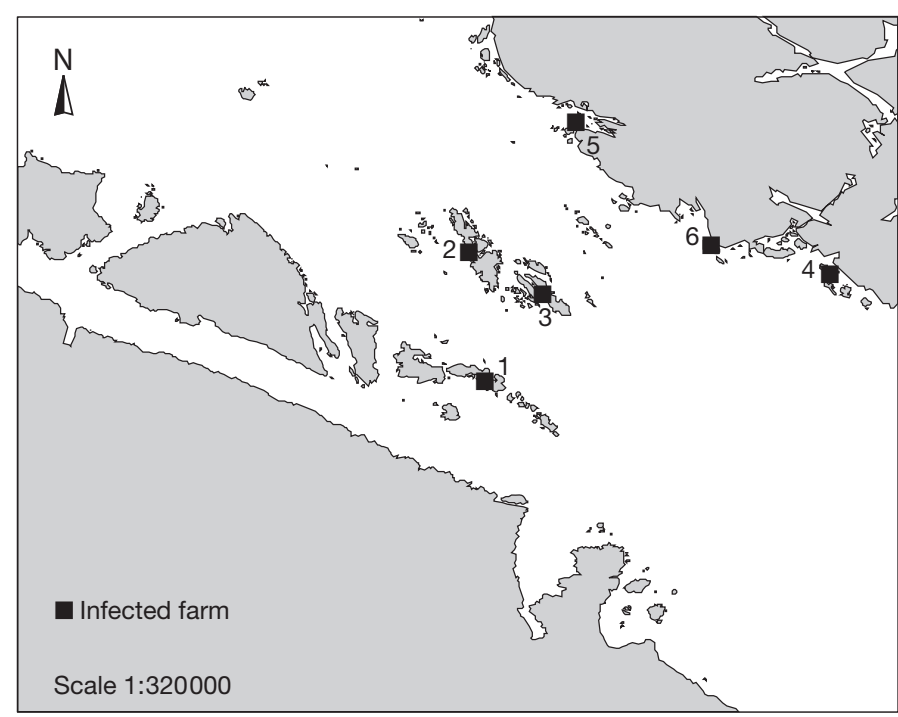

Fig. 6. Salmo salar. Locations of farms diagnosed with IHNV (numbered) and the uninfected farms in Area 4. Numbers refer to outbreak no. in the area (Table 1). For map showing all locations see Fig. 1

farms which underwent an outbreak were depopulated by February 2004. The farms were cleaned and left unpopulated prior to restocking. The shortest fallow period was $10.5 \mathrm{wk}$.

The final area to contract IHNV was located on the west coast of Vancouver Island, near Tofino (Fig. 7). All the farms in the area were operated by a single aquaculture company. The virus isolated from this area (Sequence B) differed from isolates obtained from the other affected areas (Areas 1 to 4). The first outbreak occurred on a farm containing smolts in March 2002.

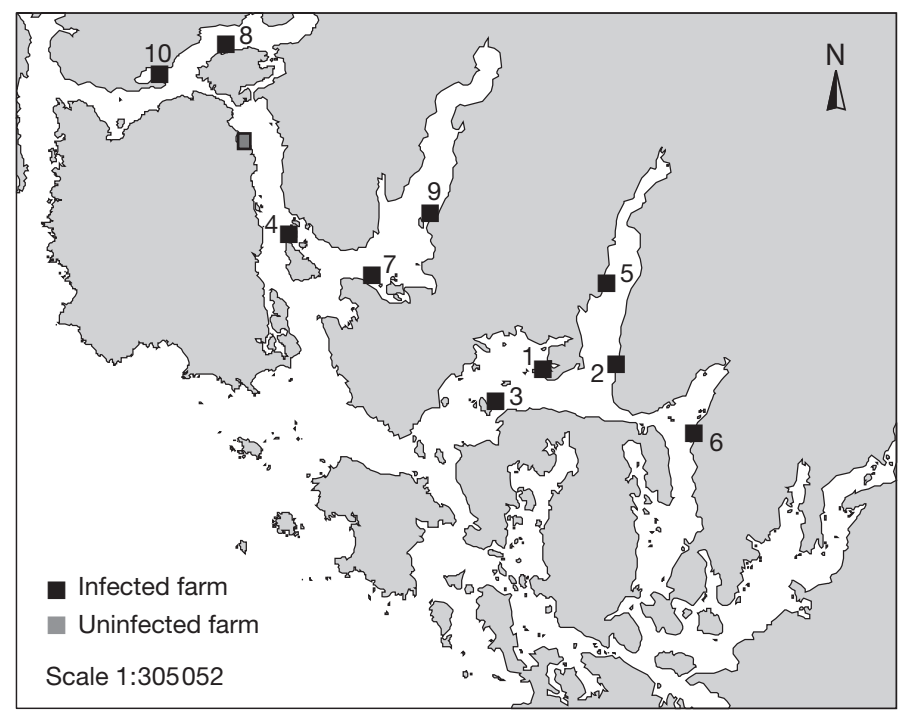

Fig. 7. Locations of $10 \mathrm{IHNV}$ cases (numbered) and the 1 uninfected farm in Area 5. Numbers refer to outbreak no. in the area (Table 1). For map showing all locations see Fig. 1
In total, 10 of 11 farms (91\%) operating in Area 5 experienced IHNV outbreaks. All the farms with IHNV exposed populations were depopulated by the end of 2003. Each farm was cleaned and fallowed for a minimum of 3 mo prior to restocking.

In all affected areas (with the exception of Area 3, where only 1 farm was affected), once one farm experienced an IHNV outbreak, outbreaks on other farms followed. Locations of farms relative to other farms where outbreaks had already occurred were examined (Table 1). One-third (12) of the farms that experienced IHNV outbreaks were situated downstream from previously infected farms. Of these downstream farms, 11 were located $10 \mathrm{~km}$ or less from the affected farm (Table 1). Of the 11 downstream farms, 9 (82\%) were operated by the same company as the affected upstream farm. Of the 11 farms (including the 2 farms) that did not share operations with the upstream farm, 6 contracted IHNV between 2 and 6 wk after the farm located upstream. More than $85 \%$ of the unaffected farms were located either upstream of the closest affected or in another bay or channel farm. There were 2 farms unaffected by IHNV which were located downstream from an outbreak farm; both were located $>10 \mathrm{~km}$ from an outbreak farm.

Of the farming operations that had IHNV outbreaks, $34(94 \%)$ operated as single year, single species sites, with fallowing occurring between production cycles. The 2 exceptions were the farm that introduced Chinook smolts while there were still harvest-sized Atlantic salmon on site, and a dedicated Atlantic salmon broodstock farm. All the Atlantic salmon had been vaccinated with 1 of 2 commercially available bacterin vaccines produced by 2 international aquaculture vaccine companies (Microtek International and Novartis Animal Health). In 6 (17\%) of the IHNV outbreaks, the affected salmon population had been vaccinated against IHNV using an autogenous vaccine (produced by a commercial vaccine supplier) at the specific request of an aquaculture company. Data collected from farms $(n=3)$ where the salmon were maintained in saltwater for the term of the outbreak showed no indication of protection. In 1 farm outbreak, the cumulative mortality was $24 \%$; this was lower than the mean of $50 \%$ for farms with salmon of similar size range. In contrast, on the 2 other farms no difference in mortality was observed, and the cumulative observed mortalities (77 and $80 \%$ respectively) were equal or higher than the average mortality (70\%) observed on farms with salmon of similar size.

The length of time required from submission of samples to receipt of laboratory confirmation ranged from 5 to $21 \mathrm{~d}$, with an average of $15.7 \mathrm{~d}$. Affected companies indicated that efforts were made to increase biosecurity and isolate farms, but only after IHNV diagnosis was confirmed; it was suggested that this 
was due to significant costs associated with making the changes. Measures taken included ceasing any movement of equipment and fish between farms, restricting movement of personnel between farms, informing contract delivery services to alter routes, and instigating harvest procedures of IHNV fish required by the DFO and the BCMAFF. Several of the affected farms indicated that they had difficulty controlling extraneous boat activity around the site both prior to and even during on-farm outbreaks.

All affected farms increased mortality retrieval by increasing frequency of mortality diving; in addition, several farms (56\%) either had or installed additional mortality retrieval systems (i.e. uplift systems) in an attempt to better manage the increased mortality levels. In 2 outbreaks, the farms attempted to control the infection by culling pens exhibiting clinical signs; this, however, did not stop the progression of the disease on the farm; 7 farms chose to cull the entire population on site.

Just prior to their outbreaks (Case nos. 12,16, 26) 3 farms received Atlantic salmon from another saltwater farm, with 2 of these farms receiving salmon from a farm that was diagnosed with IHNV shortly after the move occurred (Case nos. 16 and 26). There were 3 farms that had recently transferred fish or were in the process of moving fish when they contracted IHN. Of these, 2 farms indicated that the salmon had been towed from one farm to the other in open net pens. A group of salmon may have contracted IHNV after being towed in pens past a farm suspected of having IHNV (not yet confirmed). Finally, 3 smolt farms contracted IHNV shortly after smolt delivery. For 2 of these farms, smolts had been transported by well boat through Area 1 en route to the farms in November to January 2001/2002. The third farm was the first case of IHNV (Sequence B) diagnosed on the west coast of Vancouver Island (March 2002). Negative viral test results from freshwater testing indicate that it is unlikely that smolts had been exposed to IHNV while still at the freshwater hatcheries.

Salmon from infected populations were stunned and bled on the farm and then shipped and trucked to processing plants for processing. All water associated with harvesting and processing including blood water was contained, chlorinated (with levels required to reach $5 \mathrm{ppm}$ active chlorine for a minimum of $10 \mathrm{~min}$ ) and dechlorinated (using sodium thiosulphate to a reach a chlorine level of $<0.01 \mathrm{ppm}$ ) prior to discharge. Harvesting salmon from infected farms started in December 2001 using this protocol. During this same month, 2 other companies were transporting smolts up Johnstone Strait through Area 1 to farms located in Areas 2 and 3. Both these companies had similar protocols in place to cease pumping water into the fish holds from
$40 \mathrm{~km}$ upstream from the channel containing IHNV infected farms to $27 \mathrm{~km}$ downstream from the point where the harvested fish from infected farms were being offloaded onto trucks. Both companies however, were pumping water into the fish holds as they travelled past a facility processing the salmon and treating the contaminated water. Treated water was discharged back into the passage. The processing plant was located just upstream or south of the 'water turn-off' point. Both these smolt farms contracted IHNV and all the smolts were eventually culled. When the 'water turn-off' point was re-adjusted and started $25 \mathrm{~km}$ south of the processing plant, no further IHNV outbreaks occurred on farms with newly introduced smolts in Areas 1 to 4 .

Many of the participants observed wild migratory fish in the vicinity of the farms at the time of, or prior, to their outbreaks. The first 3 farms to contract IHNV observed a large number of returning wild Pacific salmon including sockeye, chinook and coho salmon in the channel prior to the outbreak, while 11 of the farms, which contracted IHNV in the early part of 2002 and 2003, noted significant numbers of Pacific herring Clupea harengus and pilchard Sardonops sagax in the vicinity of the farms prior to the outbreak. This included the first farm to experience IHNV in Area 5, which had a test fishery for herring not too far from the pen system.

\section{DISCUSSION}

Between August 2001 and June 2003, 36 Atlantic salmon farms in BC contracted IHNV. This constituted over $50 \%$ of all Atlantic salmon seawater farms in the province. Over 12 million farmed Atlantic salmon died or were culled as a result of the epidemic. Cumulative mortality data revealed that farm level mortality during the recent epidemic was similar to or perhaps slightly higher than the levels reported in the previous 1992 to 1996 epidemic: 58.0 and $46.5 \%$ respectively (St-Hilaire et al. 2002). Mortality was highest in smolt populations and decreased with increasing size and age of the salmon population; similar to the observations in the 1992 to 1996 epidemic (St-Hilaire et al. 2002).

Sequencing analysis of the IHNV isolates $(n=20)$ obtained during the 2001 to 2003 epidemic revealed similarities between isolates collected from farm outbreaks located in Areas 1 through 4 (Sequence A), but there were distinctive from isolates collected from outbreak farms located in Area 5 (Sequence B) (G. Kurath \& G. S. Traxler pers. comm.). The isolates were similar to those obtained in Alaska, BC, and Washington State (U genogroup, within the $2 \%$ nucleotide diversity range) and not the same as isolates collected during 
the 1992 to 1996 epidemic. These data suggest that the 2001 to 2003 epidemic consisted of 2 separate viral introductions, one affecting farms on the east coast of Vancouver Island and the other affecting farms on the west coast of Vancouver Island, both of which differed from the virus in the 1992 to 1996 epidemic.

Infectious haematopoietic necrosis outbreaks on affected farms lasted between 20 and $22 \mathrm{wk}$, with peak mortalities occurring 6 to $8 \mathrm{wk}$ after onset. This is similar to the findings for the 1992 to 1996 epidemic investigation (St-Hilaire et al. 2002). St-Hilaire et al. 2002, however, also reported a second mortality spike that occurred 30 wk following the initial spike in mortality. This was not observed during the 2001 to 2003 epidemic in the farms $(n=7)$ that maintained stocks for more than 30 wk following the outbreak.

In both epidemics, the first outbreak (index case) of IHNV occurred on a farm located in Area 1 during the summer months - July for the 1992 to 1996 epidemic (St-Hilaire et al. 2002) and August for the 2001 to 2003 event. Interestingly, the 3 farms in Area 1 which did not contract IHNV in this recent epidemic did so during the 1992 to 1996 epidemic, with 1 of the farms being the index case in 1992. The entire 1992 to 1996 epidemic was contained within Area 1, even though there were Atlantic salmon farms present in other regions including Areas 2, 4 and 5 (St-Hilaire et al. 2002). In contrast, during the 2001 to 2003 epidemic, IHNV outbreaks occurred on farms located in 4 other areas in addition to Area 1. No outbreaks occurred on Atlantic salmon farms in regions located south of Area 1 and north of Area 5. The epidemic in Area 5 was determined to be a separate isolate (G. Kurath \& G. S. Traxler pers. comm.) with its index case occurring in March 2002.

During the 2001 to 2003 epidemic, no farms experienced more than 1 outbreak, in contrast to the 1992 to 1996 epidemic, in which 18 cases of IHNV were reported on 14 farms (St-Hilaire et al. 2002). Investigation of the 1992 to 1996 epidemic suggested that in 2 of the farms which reported a second outbreak, new smolts became infected after being placed on a farm with an existing group of larger salmon that had survived an outbreak and may then have included carriers for IHNV (St-Hilaire et al. 2001a,b,c, 2002). During the early and mid-1990s, multiple-year-class farms (farms containing salmon populations with seawater entry dates $>8$ mo apart) were common; however, the generally accepted practice in BC salmon farming has switched to maintaining single year class and for the most part single species sites with fallowing between restocking. The 2 exceptions during the recent epidemic were a farm which started stocking chinook salmon smolts while harvesting of Atlantic salmon was ongoing, and the Atlantic broodstock farm.
In an attempt to halt farm-to-farm spread, all affected Atlantic salmon farms in both Areas 1 and 3 were depopulated prior to restocking any of the farms; 7 IHNV infected farms acted quickly and elected to cull their entire population of salmon in an attempt to control the spread of IHNV to neighbouring farms. The length of time between the first and last reported farm IHNV outbreak was 42 and 22 mo during the 1992 to 1996 and 2001 to 2003 epidemics respectively (StHilaire et al. 2002). Although more outbreaks occurred during the more recent IHNV epidemic, the above mentioned practices may have contributed to a decrease in its overall duration.

Atlantic salmon are considered to be more susceptible to IHNV than sockeye salmon, producing and (presumably) releasing higher titres of virus (Traxler et al. 1993). This appears to be consistent with reported observations, whereby transmission within the farms was rapid and associated mortality was high. The occurrence of outbreaks on multiple farms in 4 of the 5 affected regions suggests that once IHNV is diagnosed on a farm in an area the risk of spread to other farms in the region increases. The IHNV vaccines available at the time of the 2001 to 2003 epidemic appeared to have provided little to no protection in the farm populations that used them $(n=6)$.

Much of coastal $\mathrm{BC}$, including the regions where salmon farms are present, has estuarine circulation, i.e. net seaward movement of surface water (Thomson 1981, D. Stucchi pers. comm.). It was therefore possible to categorise farm locations in relation to other farms by the predominant direction of surface water flow (e.g. upstream, downstream, cross-stream, other). The examination of the spatial data showed that farms located $10 \mathrm{~km}$ or less downstream from an infected farm developed IHN, with over half becoming infected between 2 and 6 wk following the outbreak in the upstream farm. Waterborne transmission may have played a role in the spread of IHNV during the epidemic. The IHN virus is capable of surviving temporarily in saltwater, with $0.1 \%$ of IHN virus still active after $2 \mathrm{wk}$ in saltwater at $15^{\circ} \mathrm{C}$ (Toranozo \& Hetrick 1982). Virus survival may be even longer at lower water temperatures (Toranozo \& Hetrick 1982, Torgersen \& Hastein 1995). Reported water temperatures during the epidemic ranged from 6.7 to $12^{\circ} \mathrm{C}$. However, the observation that most of the downstream farms (9 of 11) were operated by the same company as the affected upstream farms may indicate confounding - i.e. the risk may be associated more with having a common owner than proximity to an infected farm. It is evident that more research is needed to assess viral survival in the field. Additional studies are needed to assess IHNV viral shedding rates from infected Atlantic salmon populations as 
well as the infective dose required to cause disease in Atlantic salmon.

The traditional method used in Canada to monitor for IHNV has been virus isolation (Thorburn 1996). During the 2001 to 2003 epidemic, it took between 5 and $21 \mathrm{~d}$ (mean = $15.7 \mathrm{~d}$ ) for a farm to receive conclusive laboratory diagnosis of IHNV infection. All producers surveyed implemented control measures after receiving laboratory confirmation of IHNV. These control measures included reducing fish movement between pens, culling, and accelerated harvest of smaller than desired fish. Rapid diagnostic tests are needed to ensure early recognition of infected fish and increase the speed with which control measures are implemented. Fairly early during the epidemic, the BCMAFF and the DFO established special protocols for harvesting fish from IHNV positive farms, including on-farm slaughter of the salmon, and containment and chlorine disinfection of all the harvest blood water. Several problems were apparent in this strategy. Few of the processing plants were equipped with facilities for properly treating potential IHNV-infected material. Organic material is known to inactivate chlorine to varying degrees (Torgersen \& Hastein 1995), and many of the plants could not separate organic material from the wastewater or ensure complete mixing of the chlorine and wastewater. In addition, the higher $\mathrm{pH}$ levels of seawater ( $8 \mathrm{pH}$ compared to 6.5 to $7.0 \mathrm{pH}$ of freshwater) changed the active form of chlorine from hypochlorous acid to hypochlorite. Hypochlorite is 100 times less effective as a disinfectant (Washburn \& Gillis Associates 1998) than hypochlorous acid. Those who used the prescribed protocol found that it was very difficult to reach and maintain the recommended level of chlorination in saltwater, with some noting that the addition of saltwater actually artificially increased the detectable level of chlorine. Refinement of these protocols was needed to ensure effective elimination of the virus in large volumes of water, especially when complete mixing was difficult and organic levels were high. Most plants that processed farmed salmon in BC were able to eventually set up properly engineered treatment facilities to successfully disinfect harvest by-products. However, the majority of the processing plants that handle wild fish potentially infected with IHNV still do not treat their process water prior to discharge.

Atlantic salmon population on the farm associated with the index case (Area1, Case 1) had been in seawater for more than $1 \mathrm{yr}$ and were $>3 \mathrm{~kg}$ at the onset of the epidemic, which suggests that initial exposure of the index case to the IHNV virus likely occurred in seawater. The timing of onset of both the 1992 to 1996 and 2001 to 2003 epidemics (July and August) coincides with the annual wild Pacific salmon returns, sug- gesting perhaps that wild salmon, such as sockeye salmon, may have been the initial source of the infection for the index case. Laboratory trials have also shown that Atlantic salmon develop IHNV when maintained in the same seawater tanks as IHNV infected sockeye, and the U genogroup of IHNV occurring in $\mathrm{BC}$ is known to be endemic in sockeye salmon (Traxler et al. 1993, Kurath et al. 2003). It has been suggested that sockeye salmon populations may harbour a high percentage of carriers, and presumably shed virus while migrating to spawning areas (Amend 1974, Traxler et al. 1997). Meyers et al. (2003) reported that the prevalence of IHNV in mature sockeye salmon fluctuates from year to year, and both the prevalence of infection and the proportion of infected sockeye salmon with high viral titres, are positively associated. If wild sockeye salmon are the source of the IHNV infection, then the finding reported by Meyers et al. (2003) may provide a possible explanation as to why there have been so few IHNV outbreaks in farmed Atlantic populations in BC. Exposure to adult sockeye salmon, however, does not provide a plausible explanation for the outbreaks seen in Area 5, where the isolate differed from the isolates in the other 4 areas.

Although adult sockeye salmon may play a role in the outbreaks, the outbreaks in Area 5 were associated with a different viral strain (Sequence B) and started in March, which is not the time of year when adult sockeye salmon are in the area. The only wild fish species that was observed in large numbers in Area 5 at the time of the first outbreak was Pacific herring. Although Pacific herring appear quite resistant to the disease IHN, laboratory challenge studies have shown that herring can harbour low viral titres in their tissues (Kocan et al. 1997, Traxler et al. 1998). A wild fish disease survey carried out by the DFO isolated IHNV from a single Pacific herring collected from Departure Bay on the east coast of Vancouver Island (Kent et al. 1998). It is quite evident, however, that additional research is needed to assess the role that wild fish species such as sockeye salmon and Pacific herring may play in the occurrence of IHNV epidemics in farmed Atlantic salmon in BC. Additional studies are also needed to determine the potential value of routine surveillance of wild stock in controlling the spread of IHNV.

Although the limited size of the survey $(n=36)$ precluded in-depth statistical analysis and conclusive identification of the risk factors contributing to the outbreak, all producers that reported outbreaks completed the survey instrument. The survey suggests that infected farmed salmon populations played a role in the spread of IHNV to other farms and emphasises the need for improved diagnostic tests that provide a rapid definitive assessment of infection status. Nevertheless, 
considering the fact that IHNV is endemic in wild salmon population in $\mathrm{BC}$, and that Atlantic salmon are known to be highly sensitive to the virus when exposed, disease events have been relatively rare in farmed Atlantic salmon in $\mathrm{BC}$.

Acknowledgements. I thank the British Columbia Ministry of Agriculture, Fisheries and Food (BCMAFF) and the British Columbia Salmon Farmers Association (BCSFA) for funding the study. I also thank all the companies (Atlantic salmon producers and suppliers) who participated in the study. They were all extremely cooperative and very willing to spend a considerable amount of time helping me collect and validate the information presented in this study. I am also grateful to the Department of Fisheries and Oceans Canada (DFO), the Pacific Salmon Commission, Environment Canada and the District of Campbell River for being so prompt in providing me with information. My thanks also go to G. Kurath, D. Stucchi and G. Traxler for providing me with invaluable information and J. Brackett, J. Constantine, P. Galloway, D. Hanson, L. Phillips, G. Robinson and C. Stephen for their assistance in preparing the report. A very special thank you goes to Jay Levine and Meg Thorburn for their critical evaluation and input in editing and refining the manuscript.

\section{LITERATURE CITED}

Amend DF (1974) Infectious hematopoietic necrosis (IHN) virus disease. US Fish Wildl Serv Fish Wildl Res 39

Armstrong R, Robinson JR, Rymes C, Needham T (1993) Infectious hematopoietic necrosis virus in Atlantic salmon in British Columbia. Can Vet J 34:312-313

Bootland LM, Leong JC (1999) Infectious haematopoietic necrosis virus. In: Woo PTK, Bruno DW (eds) Fish diseases and disorders, Vol 3. Viral, bacterial and fungal infections. CABI Publishing, Wallingford p 57-121

Emmenegger EJ, Kurath G (2002) Genetic Characterization of Infectious Hematopoietic Necrosis Virus of Coastal Salmonid Stocks in Washington State. J Aquat Anim Health 14:25-34

Emmenegger EJ, Meyers TR, Burton TO, Kurath G (2000) Genetic diversity and epidemiology of infectious hematopoietic necrosis virus in Alaska. Dis Aquat Org 40: 163-176

Hsu Y, Engelking HM, Leong JC (1986) Occurrence of different types of infectious hematopoietic necrosis virus in fish. Appl Environ Microbiol 52:1353-1361

Kent ML, Traxler GS, Kieser D, Richard J and 5 others (1998) Survey of salmonid pathogens in ocean-caught fishes in British Columbia, Canada. J Aquat Anim Health 10: 211-219

Kocan R, Bradley M, Elder N, Meyers T, Bratts W, Winton J (1997) North American strain of viral hemorrhagic septicemia virus is highly pathogenic for laboratory-reared Pacific herring. J Aquat Anim Health 9:279-290

Kurath G, Garver KA, Troyer RM, Emmenegger EJ, EinerJenson K, Anderson ED (2003) Phylogeography of infectious haematopoietic necrosis virus in North America. J Gen Virol 84:803-814

Meyers TR, Korn D, Burton TM, Glass K and 6 others (2003) Infectious hematopoietic necrosis virus (IHNV) in Alaskan sockeye salmon culture from 1973 to 2000: annual virus prevalences and titres in broodstocks compared with juvenile losses. J Aquat Anim Health 15:21-30

Rucker RR, Whipple WJ, Parvin JR, Evan CA (1953) A contagious disease of sockeye salmon possibly of virus origin. US Fish Wildl Serv Fish Bull 54:35-46

St-Hilaire S (2000) Epidemiology of infectious hematopoietic necrosis disease in net-pen reared Atlantic salmon in British Columbia, Canada. PhD dissertation, University of Guelph

St-Hilaire S, Ribble CS, LaPatra SE, Chartrand S, Kent ML (2001a) Infectious hematopoietic necrosis virus antibody profiles in naturally and experimentally infected Atlantic salmon Salmo salar. Dis Aquat Org 46:7-14

St-Hilaire S, Ribble C, Traxler G, Davies T, Kent ML (2001b) Evidence for a carrier state of infectious hematopoietic necrosis virus in chinook salmon Oncorhynchus tshawytscha. Dis Aquat Org 46:173-179

St-Hilaire S, Stephen C, Kent M, Ribble C (2001c) Sentinels in the bay: using farm fish to monitor for pathogens in the environment. ICES J Mar Sci 58:369-373

St-Hilaire S, Ribble CS, Stephen C, Anderson E, Kurath G, Kent ML (2002) Epidemiological investigation of infectious hematopoietic necrosis virus in salt water net-pen reared Atlantic salmon in British Columbia Canada. Aquaculture 212:49-67

Thomson RE (1981) Oceanography of the British Columbia coast. Can Spec Publ Fish Aquat Sci 56:291

Thorburn MA (1996) Apparent prevalence of fish pathogens in asymptomatic salmonid populations and its effect on misclassifying populations infectious status. J Aquat Anim Health 8:271-277

Toranozo AE, Hetrick FM (1982) Comparative stability of two salmonid viruses and poliovirus in fresh, estuarine and marine waters. J Fish Dis 5:223-231

Torgersen Y, Hastein T (1995) Disinfection in aquaculture. Rev Sci Tech OIE 14:419-434

Traxler GS, Rankin JB (1989) An infectious hematopoietic necrosis epidemic in sockeye salmon Oncorhynchus nerka in Weaver Creek spawning channel, Fraser River system, BC, Canada. Dis Aquat Org 6:221-226

Traxler GS, Roome JR, Kent ML (1993) Transmission of infectious hematopoietic necrosis virus in seawater. Dis Aquat Org 16:111-114

Traxler GS, Roome JR, Lauda KA, LaPatra S (1997) Appearance of infectious hematopoietic necrosis virus (IHNV) and neutralizing antibodies in sockeye salmon Onchorhynchus nerka during their migration and maturation period. Dis Aquat Org 28:31-38

Traxler GS, Kent ML, Poppe TT (1998) Viral diseases. In: Kent ML, Poppe TT (eds) Diseases of seawater netpen-reared salmonid fishes. Fisheries and Oceans, Science Branch, Nanaimo, p 36-45

Troyer RM, LaPatra SE, Kurath G (2000) Genetic analyses reveal unusually high diversity of infectious haematopoietic necrosis virus in rainbow trout aquaculture. J Gen Virol 81:2823-2832

Washburn \& Gillis Associates (1998) Guidelines for disinfection hygiene standards for aquaculture marine grow-out operations and associated services specific to infectious salmon anaemia. New Brunswick Department of Fisheries and Aquaculture, Fredericton

Williams IV, Amend DF (1976) A natural epidemic of infectious hematopoietic necrosis in fry of sockeye salmon (Oncorhynchus nerka) at Chilko Lake, British Columbia. J Fish Res Board Can 33:1564-1567

Submitted: August 10, 2004; Accepted: March 27, 2006

Proofs received from author(s): October 16, 2006 